\title{
BIOLOGICAL NITROGEN FIXATION OF SOME GROUNDNUTS AS AFFECTED BY GENOTYPE AND APPLIED PHOSPHORUS AT SAMARU, NORTHERN GUINEA SAVANNAH OF NIGERIA
}

\author{
${ }^{*}$ Gabasawa, A. I. and A. A. Yusuf \\ Department of Soil Science, Faculty of Agriculture/Institute for Agricultural Research, Ahmadu Bello University, \\ Zaria, Nigeria. \\ *Correspondence author: algabasawiyyu@yahoo.com
}

\begin{abstract}
Biological nitrogen fixation (BNF), brought about by both free living soil microorganisms and their symbiotic associations with higher plants, is the major source of $\mathbf{N}$ input into agricultural systems. Groundnuts (Arachis hypogaea L.), in symbiosis with rhizobia, in their root nodules, fix atmospheric nitrogen $\left(\mathrm{N}_{2}\right)$. A field trial was carried out at Samaru, Nigeria, in 2008 with a view to evaluate BNF potentials of five groundnut genotypes (SAMNUT 10, 11, 21, 22 and 23). Each genotype received four rates of $P\left(0,20,40\right.$ and $\left.60 P_{2} O_{5} h^{-1}\right)$ in an RCBD with three replications. $N$-Difference method was employed in assessing the BNF of the genotypes. Nodulation performance of the genotypes was observed. Results of the study showed that SAMNUT 11 and 22 significantly recorded the highest nodulation, by number and weight. All the remaining genotypes statistically produced same nodule number. Moreover, the early maturing SAMNUT 21 fixed the highest ( $82 \mathrm{~kg} \mathrm{~N} \mathrm{ha}^{-1}$ ) quantity of $\mathrm{N}_{2}$ while SAMNUT 11 (46 kg N ha-1) and 23 (31 kg N ha-1) were statistically similar and fixed the lowest $\mathrm{N}_{2}$. SAMNUT 11 and 22 were, therefore, found to significantly record the highest nodule number and weigh and SAMNUT 21 fixed the highest $N_{2}$, and hence the highest BNF, indicating their genotypic desirability in terms of $\mathrm{N}_{2}$ addition to the soil environment, especially for subsequent crops.
\end{abstract}

Keywords: Arachis hypogaea, Biological Nitrogen Fixation, Genotype, Phosphorus

\section{INTRODUCTION}

The symbiotic system of leguminous plants and rhizobia, as association, has the greatest quantitative impact on nitrogen $(\mathrm{N})$ cycle. A tremendous potential for contribution of fixed nitrogen $\left(\mathrm{N}_{2}\right)$ to soil ecosystems exists among legumes (Tate, 1995) thereby reducing the use of expensive fertiliser- $\mathrm{N}$ and hence enhancing soil fertility. This provides the basis for sustainable farming systems that incorporate integrated nutrient management (Hardarson and Atkins, 2002). Groundnut (Arachis hypogaea L.) is the world's $13^{\text {th }}$ most important food crop, $4^{\text {th }}$ most important source of edible oil and $3^{\text {rd }}$ most important source of vegetable protein (Taru et al., 2008). In Nigeria, the Sudan $\left(10^{\circ}\right.$ to $\left.13^{\circ} \mathrm{N}\right)$ and Northern Guinea Savannah $\left(6^{\circ}\right.$ to $\left.8^{\circ} \mathrm{N}\right)$ agro-ecological zones (AEZs) have the most favourable soil and climate conditions for groundnut production (Misari et al., 1980).

Groundnut provides a safe, cheap and renewable $\mathrm{N}$ source in the cropping systems and is, therefore, good for agriculture as well as for our environment (Vance, 2001). However, soil physical and chemical constraints, among other problems, pose an important barrier to actualizing optimum utilization of the benefits of $\mathrm{N}_{2}$-fixation (Graham and Vance, 2003). Recent study has confirmed that there is generally an inter- and intra-specific variation in the amounts of $\mathrm{N}_{2}$ fixed by legumes (Yusuf et al., 2008), usually due to many reasons including nodulation efficiencies, maturity period, et cetera.

Without adequate phosphorus (P) supply, however, BNF can have only limited success due to the high $\mathrm{P}$ requirement of the process through which legumes derive $\mathrm{N}_{2}$ from the atmosphere. In the Northern Guinea Savannah (NGS) AEZ of Nigeria, P use is mainly constrained by, among other factors, low solubility of the relatively available rock phosphate found in the tropics, which mars its direct application (Pypers et al., 2007), besides, the soluble P fertilisers are often expensive and usually vulnerable to fixation by iron (Fe) and aluminum ( $\mathrm{Al}$ ) oxides, commonly found in tropical soils, into forms unavailable to plants (Sample et al., 1980). This makes the sole dependence on commercially available $P$ fertiliserst so unreliable in redressing $P$ deficiency in the savannah AEZ.

Several research works have been conducted on the influence of genotype and nutrients on BNF and other traits' potentials using a wide array of especially such grain legumes as cowpea (Vigna unguiculata L.), soybeans (Glycine max L.) amongst others by many scientists (Sanginga et al., 2000; Yusuf et al., 2008). Not much similar studies have been conducted on groundnuts in the NGS of Nigeria and hence the need for this work. This study was therefore designed to screen five groundnut genotypes for $\mathrm{N}_{2}$-fixation.

\section{MATERIALS AND METHODS}

A field experiment was conducted in 2008 at the Institute for Agricultural Research (IAR) experimental field, Samaru (latitude $11^{0} 11^{\prime} 0^{\prime \prime} \mathrm{N}$, and longitude $7^{0}$ $366^{\prime} 52^{\prime \prime}$ E) The soil was classified as leached tropical ferruginous, Typic Haplustalf in Soil Taxonomy, Acrisol in the FAO system or Alfisol in the USDA system (Uyovbisere et al., 2000). 
Core soil samples, at the depth of $0-15 \mathrm{~cm}$ were taken at random from the field, bulked into a composite and a sub-sample taken, air-dried and sieved through a 2 $\mathrm{mm}$ mesh and analysed for some physicochemical properties as described by Anderson and Ingram (1993). The soil was loamy in texture, $\mathrm{pH}$ (water), 6.1 ; organic carbon, $0.32 \%$; total $\mathrm{N}, 0.88 \mathrm{~g} \mathrm{~kg}^{-1}$; available $\mathrm{P}, 10.5 \mathrm{mg} \mathrm{kg}^{-1}$; and exchangeable cations $\left(\mathrm{cmol}^{+} \mathrm{kg}^{-1}\right)$ of $\mathrm{Mg}^{2+}, 2.27 ; \mathrm{Ca}^{2+}, 3.62 ; \mathrm{K}^{+}, 0.36$ and $\mathrm{Na}^{+}, 2.61$.

Five groundnut (SAMNUT 10, 11, 21, 22 and 23) and three (reference) maize (Obatampa, TZE and TZEE) genotypes, all sourced from IAR, Samaru Zaria, were selected. The maize genotypes were used for estimating $\mathrm{N}_{2}$ fixation of the grain legumes using $\mathrm{N}$-difference method (Peoples et al., 1989).

The field was ridged at an inter-row spacing of $0.75 \mathrm{~m}$ after ploughing and harrowing. The experimental plot size was marked at four rows $(3 \mathrm{~m})$ by $5 \mathrm{~m}$. The plots were laid down in randomized complete block design (RCBD) with three replications. Each genotype (groundnut and maize) received four $\left(0,20,40\right.$, and $\left.60 \mathrm{~kg} \mathrm{P}_{2} \mathrm{O}_{5} \mathrm{ha}^{-1}\right)$ levels of $\mathrm{P}$ as triple super phosphate (TSP) $\left(46 \% \mathrm{P}_{2} \mathrm{O}_{5}\right)$, placed in band at about $5 \mathrm{~cm}$ away from the base of each plant stand. Three seeds of each genotype were hand-dibbled and later thinned to two plants per stand a week after sowing (WAS). The groundnut genotypes were sown at $0.2 \mathrm{~m}$ intra-row and $0.75 \mathrm{~m}$ between rows, while those of maize were planted at $0.4 \mathrm{~m}$ intra- and 0.75 $\mathrm{m}$ inter- row. All plots were hand-weeded at two and six WAS.

The first and second samplings were respectively carried out on the two outer (border) and two inner (net plot) rows. Four plants were carefully dug out from each plot. Groundnuts roots were cut from the stem, and washed with clean water. Numbers and fresh weights of nodules were recorded, and the roots and stems were separately canvassbagged and oven-dried to constant weight at $70^{\circ} \mathrm{C}$. The maize roots were also separated and the stems sliced, canvass-bagged separately and also oven-dried at $70^{\circ} \mathrm{C}$ for two days. The samples were then ground, passed through 500- $\mu \mathrm{m}$ sieve and analysed for $\mathrm{N}$. During the second sampling, however, nodule number was recorded and samples from haulm were ground, sieved through the $500-\mu \mathrm{m}$ sieves and also analysed for N. The stover was ground, sieved through $500-\mu m$ sieve and analysed for $\mathrm{N}$. Difference between the groundnut and maize $\mathrm{N}$ analysed was recorded. The generated data were subjected to analysis of variance (ANOVA) using the SAS statistical package (SAS, 1999). Significantly different means were separated using the Duncan New Multiple Range Test as described by Duncan (1955).

\section{RESULTS AND DISCUSSION Nodule Number and Weight}

There was no significant $(P \geq 0.05)$ difference between $\mathrm{P}$ rate and its interaction with genotype in terms of number of nodules per plant. However, genotype had significantly $(P<0.0001)$ influenced the nodule number, and weight (Table 1 ). In that,
SAMNUT 11 and 22 recorded the highest mean number of nodules, while the remaining genotypes recorded statistically similar and the least number of nodules. Phosphorus rate did not influence the nodule number of the genotypes. Legume may provide an environment conducive to sustained bacterial metabolism by reducing the external free oxygen $\left(\mathrm{O}_{2}\right)$ level and providing a source of energy usually in form of succinate and malate (Hardarson and Atkins, 2002). This may be the reason why $P$ rate, and possibly the soil, did not significantly influence the nodulation, and consequently the nodule weight, but the genotype.

SAMNUT 11 statistically produced the highest weight of nodules followed by SAMNUT 22. The three other genotypes did not however, differed significantly in mean weight of nodules per plant (Fig. 1). There was a significant $(P<0.0001)$ interaction between genotype and $P$ in terms of nodule weight (Fig. 1). Significantly higher weight of nodule was recorded at 0 and $20 \mathrm{~kg} \mathrm{P}_{2} \mathrm{O}_{5}$ ha $^{-1}$ and the lowest at 40 and $60 \mathrm{~kg}$ $\mathrm{P}_{2} \mathrm{O}_{5}$ ha $^{-1}$ in SAMNUT 11 (Fig. 1). Similar observations were reported by Sanginga et al. (2000) who recorded increased nodule weight with $\mathrm{P}$ application. However, on the contrary Ahmed et al. (2000) reported lower number and dry weight of nodules with an increase in P level.

A study by Lekberg and Koide (2005) corroborated the fact that nodule formation in groundnuts is strongly associated with available soil $P$. In their experiment, they concluded that $\mathrm{P}$ addition significantly increased both nodule number and shoot $\mathrm{N}$ content. This indicates the importance of $\mathrm{P}$ for $\mathrm{N}_{2}$ fixation. The inherent soil $P\left(10.5 \mathrm{mg} \mathrm{kg}^{-1}\right)$ might, however, be at play for the high nodule weights at 20 and even at $0 \mathrm{P}$ rates.

\section{Fixed Nitrogen}

Genotype had significantly $(P<0.0001)$ influenced the $\mathrm{N}_{2}$ fixed, but neither the $P$ rate nor its interaction with genotype had any significant $(P \geq 0.05)$ influence on the $\mathrm{N}_{2}$ fixed. SAMNUT 21 fixed the highest amount of $\mathrm{N}_{2}$. It was followed by SAMNUT 10 and 22, which were statistically similar. SAMNUT 11 and 23 were at par and fixed the lowest $\mathrm{N}_{2}$ of 46 and $31 \mathrm{~kg} \mathrm{~N} \mathrm{ha}^{-1}$ respectively (Table 1 ).

Provenances of some legumes, like Gliricidia sepium, can nodulate and fix $\mathrm{N}_{2}$ at different levels when established in same field. Presence of a proper genotype-bradyrhizobium strain interaction also maximises $\mathrm{N}_{2}$ fixation in acid soils, like ours, although at the same time low soil $\mathrm{pH}$ can reduce the rate at which root nodules are formed. Groundnut and cowpea are however, the most tolerant legumes to soil acidity especially when compared to soybeans or Phaseolus vulgaris (Munns, 1978). O'Hara et al. (1989) reported that some bacterial symbionts are not affected by low $\mathrm{pH}$ as they are capable of regulating their internal $\mathrm{pH}$ thereby having an increased survival rate at the low $\mathrm{pH}$. Some Strains of Bradyrhizobium, for example were tested to be more tolerant of aluminium than Bradyrhizobium japonicum strains (Johnson and Wood, 1990). 
Table (1) Number and Weight of Nodules Plant ${ }^{-1}$; and Fixed Nitrogen as Affected by

\begin{tabular}{|c|c|c|}
\hline Treatment & $\begin{array}{l}\text { Nodule Number } \\
\left.\text { (Plant }^{-1}\right)\end{array}$ & $\begin{array}{l}\text { Fixe } \\
\text { (kg }\end{array}$ \\
\hline \multicolumn{3}{|c|}{ Genotype (G) } \\
\hline SAMNUT 10 & $42.71^{b}$ & $63^{b}$ \\
\hline SAMNUT 11 & $85.12^{\mathrm{a}}$ & 46 \\
\hline SAMNUT 21 & $54.41^{\mathrm{b}}$ & $82^{\mathrm{a}}$ \\
\hline SAMNUT 22 & $95.63^{a}$ & 53 \\
\hline SAMNUT 23 & $34.04^{\mathrm{b}}$ & $31^{d}$ \\
\hline SE \pm & 6.868 & 5.3 \\
\hline \multicolumn{3}{|c|}{ Phosphorus $\left(\mathrm{P}_{2} \mathrm{O}_{5}\right)$} \\
\hline 0 & 63.53 & 58 \\
\hline 20 & 66.59 & 50 \\
\hline 40 & 61.61 & 56 \\
\hline 60 & 57.80 & 55 \\
\hline SE \pm & 6.143 & 4.77 \\
\hline \multicolumn{3}{|l|}{ Interaction } \\
\hline $\mathrm{G} \times \mathrm{P}$ & NS & NS \\
\hline
\end{tabular}

NS=Not Significant at $5 \%$ level of probability; Means followed by same letter(s) within a treatment in a column do not differ significantly according to DMRT.

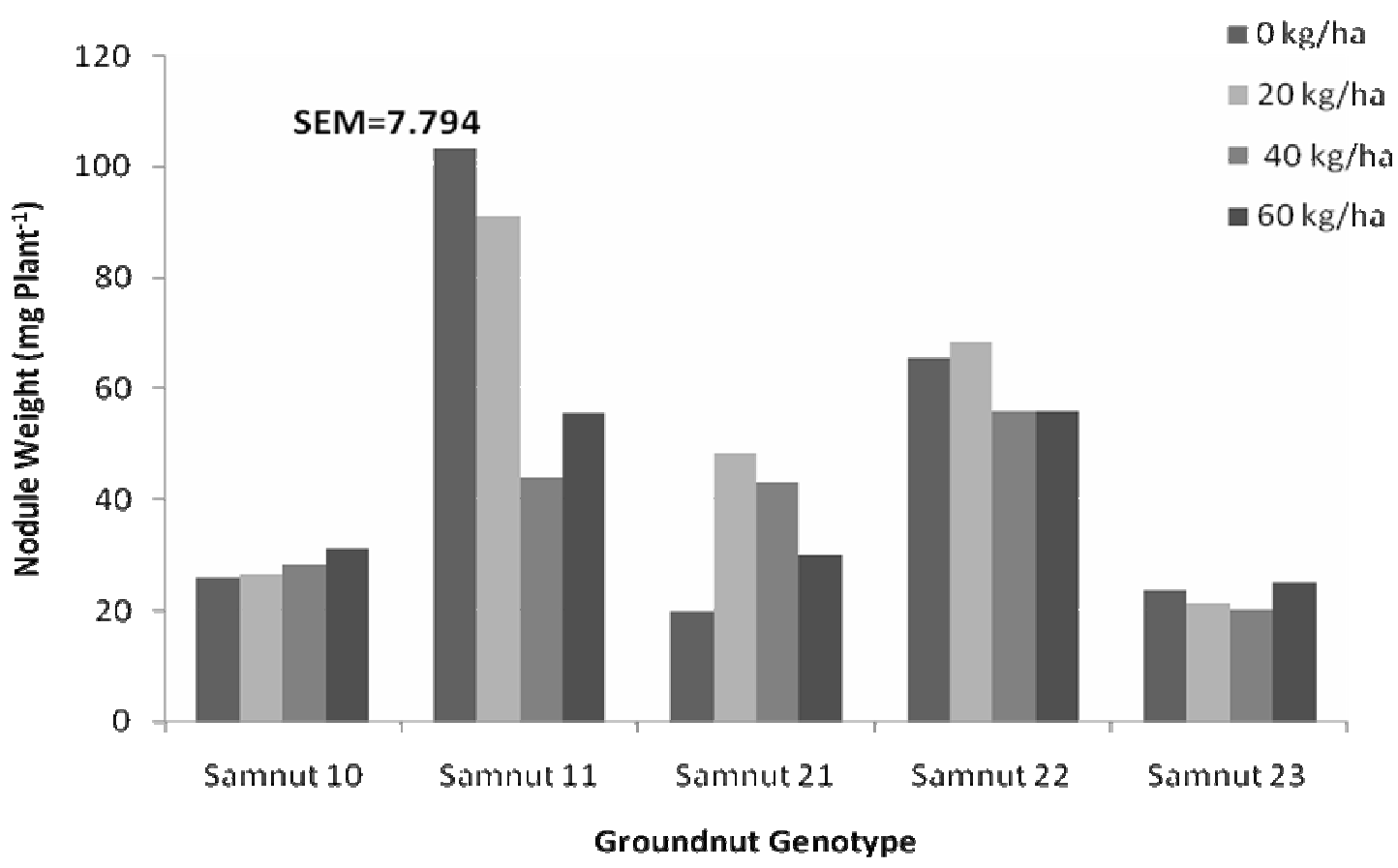

Fig. 1 Effect of Genotype-Phosphorus Interaction on Nodule Weight (mg/Plant)

\section{CONCLUSION}

Contribution of grain legumes to the soil $\mathrm{N}$ balance depends on the amount of fixed $\mathrm{N}_{2}$ returned to the soil and the soil $\mathrm{N}$ in the harvested plants parts. Among the groundnut genotypes tested, SAMNUT 11 and 22 significantly had the highest numbers and weights of nodules, while SAMNUT 21 fixed the highest quantity of biological N. SAMNUT 21, 10 and, to some extent, SAMNUT 11 and 22 can, therefore, be incorporated in legume-cereal cropping systems of similar soil types in order to judiciously reap advantage of the residual $\mathrm{N}$ fixed into the soil by the genotypes. This therefore, implies that by virtue of all the parameters observed, if judiciously used, the genotypes can successfully supplement the quantity of nitrogenous fertilizers to be applied to agricultural soils. This will invariably reduce the cost of production of the resource-poor farmer, besides the control of vulnerability of soils to serious acidity problems and other forms of soil and water pollutions caused by nitrogenous fertilisers.

Further studies relating to the genotypic root architectural differences among the groundnut genotypes, amongst others, would be an important step towards understanding the phenomenon more. 


\section{Acknowledgements}

The authors acknowledge the assistance of the Legumes and Oil Seeds Research Programme of the Institute for Agricultural Research (IAR), Ahmadu Bello University, Samaru-Zaria, Nigeria, the technical

\section{REFERENCES}

Ahmed, F.E., Yagoub, S.O. and Elsheikh, E.A.E. (2000). Effects of Mycorrhizal Innoculation and Phosphorus Application on the Nodulation, Mycorrhizal Infection and Yield Components of Faba Bean Grown under Two Different Watering Regimes. $U$ of Karnataka J. Agric. Sci. 2: 107-116.

Anderson, J.M. and Ingram, J.S.I. (1993). Tropcal Soil Biology and Fertility: A Handbook of Methods', C.A.B. International Walling-Ford, U.K.

Blair, G. (1993). Nutrient Efficiency - What Do We Really Mean? In: Randall, P.J. (Ed.). Genetic Aspects of Plant Mineral Nutrition', Kluwer Academic Publishers, Netherlands, pp. 205-213.

Duncan, D.B. (1955). Multiple Range and Multiple $F$ Tests. Biometrics. 11: 1-42.

Graham, P.H and Vance, C.P. (2003). Legumes: Importance and Constraints to Greater Utilization. Plant Physiol. 131: 872-877. In: Yusuf, A.A., Abaidoo, R.C., Iwuafor, E.N.O. and Olufajo, O.O. Genotype Effects of Cowpea and Soybean on Nodulation, $\mathrm{N}_{2}$ fixation and $\mathrm{N}$ Balance in the Northern Guinea Savanna of Nigeria. Journal of Agronomy. 7: 258-264.

Hardarson G. and Atkins, C. (2002). Optimizing Biological $\mathrm{N}_{2}$-Fixation by Legumes in Farming Systems'. Pp. 41-54. Kluver Academic Publishers.

Johnson, A. and Wood, M. (1990). DNA, A Possible Site of Action of Aluminium in Rhizobium spp. Applied and Environmental Microbiology. 56: 3629-3636.

Lekberg, Y. and Koide, R.T. (2005). Arbuscular Mycorrhizal Fungi, Rhizobia, Available P and Nodulation of Groundnut (Arachis hypogaea) in Zimbabwe. Agriculture Ecosystems Environment. 110: 143-148.

Misari, S.M., Harkness, C. and Fowler, M. (1980). Groundnut Production, Utilization, Research Problems and Further Research Needs in Nigeria. International Workshop on Groundnuts, Patancheru, India, pp: 264-273.

Munns, D.N. (1978). Soil Acidity and Nodulation. In: Andrew, C.S. and Kamprath, E.J. (Eds.). Mineral Nutrition of Legumes in Tropical and Subtropical Soils. CSIRO, Melbourne, Australia, pp. 247-264.

O'Hara, G.W., Goss, T.J., Dilworth, M.J. and Grenn, A.R. (1989). Maintenance of Intracellular $\mathrm{pH}$ assistance, in the field and/or laboratory, of Messrs U. O. Bello, A. Jibrin, and I. Ibrahim, all of the Department of Soil Science, ABU, and all those that contributed to the success of this work.

and Acid Tolerance in Rhizobium meliloti. Applied and Environmental Microbiology. 55: 1870-1876.

Peoples, M.B., Faizah, A.W., Rerkasem, B. and Herridge, D.F. (1989). Methods for Evaluating Nitrogen Fixation by Nodulated Legumes in the Field'. ACIAR, Camberra.

Pypers, P., Huybrighs, M., Diels, J., Abaidoo, R.C, Smolders, E. and Merckx, R. (2007). Does the Enhanced $P$ Acquisition by Maize Following Legumes in a Rotation Result From Improved Soil P Availability?' Soil Biology \& Biochemistry. 39: 25552566.

Sample, E.C, Soper, .R.J. and Racz, G.J. (1980). Reaction of Phosphate Fertilizers in Soils', in N. Sanginga, O. Lyasse \& BB Singh, Phosphorus Use Efficiency and Nitrogen Balance of Cowpea Breeding Lines in a Low P Soil of the Derived Savanna Zone in West Africa, Plant and Soil. 220: 119-128.

Sanginga, N., Lyasse, O. and Singh, B.B. (2000). Phosphorus Use Efficiency and Nitrogen Balance of Cowpea Breeding Lines in a Low $\mathrm{P}$ Soil of the Derived Savannah Zone in West Africa', Plant and Soil. 220: 119-128.

Statistical Analysis System Institute (1999). SAS 6.12, SAS Institute, Inc., Cary, NC.

Taru, V.B., Kyagya, I.Z., Mshelia, S.I. and Adebayo, E.F. (2008). Economic Efficiency of ResourceUse in Groundnut Production in Adamawa State of Nigeria. World Journal of Agricultural Sciences. 4: 896-900.

Tate, R.L. (1995). Soil Microbiology (Symbiotic Nitrogen Fixation). John Wiley \& Sons, Inc., New York, N.Y.

Uyovbisere, E.O., Chude, V.O. and Bationo, A. (2000). Promising Nutrient Ratios in Fertiliser Formulations for Optimal Performance of Maize in the Nigerian Savannah: The need for a Review of Current Recommendation. Nig. J. Soil Res. 1: 29-34.

Vance, C.P. (2001). Symbiotic Nitrogen Fixation and Phosphorus Acquisition. Plant Nutrition in a World of Declining Renewable Resources. Plant Physiol. 127: 390-397.

Yusuf, A.A., Abaidoo, R.C., Iwuafor, E.N.O. and Olufajo, O.O. (2008). Genotype Effects of Cowpea and Soybean on odulation, $\mathrm{N}_{2}-$ fixation and $\mathrm{N}$ Balance in the Northern Guinea Savavanna. Agronomy. 7: 258-264. 